\title{
УДК 372.8 \\ ПРОГРАМА НАВЧАЛЬНОЇ ДИСЦИПЛІНИ “АКАДЕМІЧНЕ ПИСЬМО АНГЛІЙСЬКОЮ МОВОЮ" ДЛЯ ПІДГОТОВКИ ЗДОБУВАЧІВ НАУКОВОГО СТУПЕНЯ ДОКТОРА ФІЛОСОФІЇ В ГАЛУЗІ ПРАВА
}

\author{
Трубчанінова Т. А., Жигадло О. Ю., Заярна І. С., Клавдіч В. О. \\ tatrubchaninova@gmail.com; olena.zhygadlo@gmail.com; \\ izaiarna@gmail.com; victoria.klavdich@gmail.com; \\ Київський національний університет імені Тараса Шевченка \\ Дата надходження 30.11.2020. Рекомендовано до друку 27.12.2020.
}

\begin{abstract}
Анотація. Програму розроблено для аспірантів другого року навчання за освітньо-науковою програмою підготовки докторів філософії зі спеціальності 081 "Право”. Метою навчальної дисципліни є формування базових навичок академічного письма англійською мовою, які передбачають перефразовування, анотування, структурування та створення англомовних текстів наукового характеру, зокрема, наукову статтю й анотацію до неї. Очікувані результати передбачають вміння ефективно представляти свої наукової напрацювання англійською мовою у вітчизняних та зарубіжних наукових виданнях. Окрім лексичних і граматичних особливостей жанру англомовного академічного письма, значну увагу в програмі приділено питанням академічної доброчесності й засобам запобігання плагіату. У робочій програмі також окреслено форми викладання дисципліни, описано методи й організацію оцінювання результатів навчання та надано список рекомендованих джерел.

Ключові слова: спеціальність 081 “Право”, структура навчальної дисципліни, структурно-композиційні особливості текстів, академічний дискурс, анотація, перефразування.
\end{abstract}

Трубчанинова Т. А., Жигадло Е. Ю., Заярна И С., Клавдич В. А. Киевский национальный университет имени Тараса Шевченко

Программа учебной дисциплины “Академическое письмо на английском языке” для подготовки соискателей ученой степени доктора философии в сфере права

Аннотация. Программа разработана для аспирантов второго года обучения по программе подготовки докторов философии, специальность 081 “Право”. Цель дисциплины - формирование базовых навыков академического письма на английском языке, которые включают перефразирование, аннотирование, структурирование и создание англоязычных текстов научного характера, в частности, научную статью и аннотацию к ней. Результатом обучения является умение эффективно представлять свои научные взгляды на английском языке в отечественных и зарубежных научных изданиях. Кроме лексических и грамматических особенностей жанра англоязычного академического письма, существенное внимание в программе уделяется вопросам академической порядочности и средствам предотвращения плагиата. Также в рабочей программе описаны формы преподавания дисциплины, методы и процедура оценивания результатов обучения, а также представлен список рекомендуемой литературы.

Ключевые слова: специальность 081 “Право”, структура учебной дисциплины, структурно-композиционные особенности текстов, академический дискурс, аннотация, перефразирование.

Trubchaninova T., Zhygadlo O., Zaiarna I., Klavdich V. Taras Shevchenko National University of Kyiv English academic writing course syllabus for $\mathrm{PhD}$ students in law

Abstract. The course is aimed at the second-year-of-study PhD students in law. The goal of the course is to form essential skills of academic writing in English, which consist in paraphrasing, summarizing, structuring and creating academic texts in English, in particular, the abstract and the research paper. The expected results include the ability of legal scholars to effectively present their scientific findings in the English language in Ukrainian and foreign scientific journals. In addition to lexical and grammatical features of English academic discourse, the course syllabus pays special attention to the issues of academic integrity and means of preventing plagiarism. The course syllabus also outlines the methods of teaching, gives the overview of the assessment procedure of learning outcomes and objectives and provides the reading list with references to online readings.

Key words: specialty 081 "Law", course syllabus, structural and compositional features of texts, academic discourse, abstract, paraphrasing. 
1. Мета дисципліни полягає у формуванні в аспірантів мовленнєво комунікативної компетентності у створенні англомовних писемних текстів наукового характеру, необхідних для ефективної науково-дослідної діяльності вчених-правників.

2. Попередні вимоги до опанування навчальної дисципліни:

1. Знати правила англійського синтаксису, мовних форм і граматичних конструкцій, необхідних для розуміння і говоріння в юридичній сфері; мати широкий діапазон словникового запасу юридичної лексики.

2. Вміти працювати з фаховою англомовною літературою з метою отримання професійно значущої інформації та ії подальшого використання; використовувати вивчений лексичний матеріал у підготовленому та спонтанному усному та письмовому мовленні; використовувати термінологічний запас лексичних одиниць відповідних галузей права при комунікації (усній та письмовій); давати визначення різноманітним поняттям і галузям права 3 використанням відповідної термінологічної бази; користуватися програмами в межах стандартного програмного забезпечення для оформлення проєктів / презентацій; грамотно, логічно й аргументовано формулювати та висловлювати свою позицію; ефективно доносити власну думку, бути здатним обстоювати свою позицію шляхом надання аргументованої відповіді.

3. Володіти навичками визначення основної думки, логічної структури та важливих деталей текстової й усної інформації; отримання інформації з іншомовних джерел та їх використання 3 освітньою метою; відповідально ставитися до підготовки завдань різних типів; вміти самостійно працювати при підготовці до семінарських занять, доповідей, презентацій та інших творчих завдань; вміти організувати роботу в команді під час підготовки презентацій та інших спільних проєктів.

3. Анотація навчальної дисципліни. Курс знайомить аспірантів і здобувачів із практикою академічного письма англійською мовою та спрямований на формування знань і практичних навичок, необхідних для написання наукових текстів різних жанрів. За результатами вивчення курсу аспіранти та здобувачі зможуть зв'язно формулювати думку у наукових текстах; оперувати загальнонауковою лексикою; вживати граматичні структури, характерні для наукового стилю; структурувати науковий текст (членувати текст на пункти/абзаци); розвинути навички перефразування, формулювання тез й оформлення посилань; удосконалювати навички написання наукових текстів різних жанрів; демонструвати результати власних наукових досліджень англійською мовою на міжнародному рівні.

4. Завдання дисципліни спрямовані на досягнення аспірантами таких компетентностей, як зв'язне й аргументоване формулювання та висловлення своїх наукових поглядів, коректне застосування посилань на праці інших дослідників з позиції академічної доброчесності, ведення наукової дискусії $з$ міжнародною науковою спільнотою письмово англійською мовою; написання англійською мовою текстів різних жанрів у межах наукового дискурсу, зокрема анотацій і наукових статей, враховуючи особливості їхніх структурно-композиційних частин; оформлення цитувань і посилань відповідно до основних міжнародних стандартів.

5. Результати навчання за дисципліною:

\begin{tabular}{|c|c|c|c|c|}
\hline \multicolumn{2}{|c|}{$\begin{array}{l}\text { Результат навчання } \\
\text { (1. знання; 2. вміння; } \\
\text { 3. комунікація; 4. автономія } \\
\text { та відповідальність) }\end{array}$} & \multirow[t]{2}{*}{\begin{tabular}{|c|} 
Форми \\
(та/або методи \\
і технології) \\
викладання \\
і навчання
\end{tabular}} & \multirow[t]{2}{*}{$\begin{array}{c}\text { Методи } \\
\text { оцінювання }\end{array}$} & \multirow[t]{2}{*}{\begin{tabular}{|c|} 
Відсоток \\
у підсумковій \\
оцінці \\
з дисципліни
\end{tabular}} \\
\hline Код & Результат навчання & & & \\
\hline 1 & $\begin{array}{l}1.1 \text { Знати основні жанри } \\
\text { письмового академічного } \\
\text { дискурсу; }\end{array}$ & $\begin{array}{l}\text { Практичне } \\
\text { заняття, } \\
\text { самостійна } \\
\text { робота }\end{array}$ & $\begin{array}{l}\text { Фронтальне } \\
\text { опитування, } \\
\text { письмове завдання }\end{array}$ & $7 \%$ \\
\hline
\end{tabular}


Трубчанінова Т. А., Жигадло О. Ю., Заярна І. С., Клавдіч В. О. Програма навчальної дисципліни “Академічне

\begin{tabular}{|c|c|c|c|c|}
\hline \multicolumn{2}{|c|}{$\begin{array}{c}\text { Результат навчання } \\
\text { (1. знання; 2. вміння; } \\
\text { 3. комунікація; 4. автономія } \\
\text { та відповідальність) }\end{array}$} & \multirow[t]{2}{*}{$\begin{array}{c}\text { Форми } \\
\text { (та/або методи } \\
\text { і технології) } \\
\text { викладання } \\
\text { і навчання }\end{array}$} & \multirow[t]{2}{*}{$\begin{array}{c}\text { Методи } \\
\text { оцінювання }\end{array}$} & \multirow[t]{2}{*}{\begin{tabular}{|c|} 
Відсоток \\
у підсумковій \\
оцінці \\
з дисципліни
\end{tabular}} \\
\hline Код & Результат навчання & & & \\
\hline & $\begin{array}{l}1.2 \text { знати структурно- } \\
\text { композиційні та мовні } \\
\text { особливості текстів } \\
\text { англомовного академічного } \\
\text { дискурсу; }\end{array}$ & $\begin{array}{l}\text { Практичне } \\
\text { заняття, } \\
\text { самостійна } \\
\text { робота }\end{array}$ & $\begin{array}{l}\text { Фронтальне } \\
\text { опитування, } \\
\text { письмове завдання, } \\
\text { індивідуальний } \\
\text { проєкт, тест, } \\
\text { підсумкова } \\
\text { контрольна робота }\end{array}$ & $7 \%$ \\
\hline & $\begin{array}{l}1.3 \text { знати основні типи } \\
\text { анотацій та їхні функції }\end{array}$ & $\begin{array}{l}\text { Практичне } \\
\text { заняття, } \\
\text { самостійна } \\
\text { робота }\end{array}$ & $\begin{array}{l}\text { Фронтальне } \\
\text { опитування, } \\
\text { письмове завдання, } \\
\text { тест, підсумкова } \\
\text { контрольна робота }\end{array}$ & $7 \%$ \\
\hline 2 & $\begin{array}{l}2.1 \text { Вміти ефективно } \\
\text { структурувати науковий } \\
\text { текст; }\end{array}$ & $\begin{array}{l}\text { Практичне } \\
\text { заняття, } \\
\text { самостійна } \\
\text { робота }\end{array}$ & $\begin{array}{l}\text { Фронтальне } \\
\text { опитування, } \\
\text { письмове завдання, } \\
\text { індивідуальний } \\
\text { проєкт, тест, } \\
\text { підсумкова } \\
\text { контрольна робота }\end{array}$ & $10 \%$ \\
\hline & $\begin{array}{l}2.2 \text { вміти застосовувати } \\
\text { навички перефразування; }\end{array}$ & $\begin{array}{l}\text { Практичне } \\
\text { заняття, } \\
\text { самостійна } \\
\text { робота }\end{array}$ & $\begin{array}{l}\text { Письмове завдання, } \\
\text { індивідуальний } \\
\text { проєкт, тест, } \\
\text { підсумкова } \\
\text { контрольна робота }\end{array}$ & $10 \%$ \\
\hline & $\begin{array}{l}2.3 \text { вміти правильно } \\
\text { оформлювати посилання на } \\
\text { роботи інших науковців; }\end{array}$ & $\begin{array}{l}\text { Практичне } \\
\text { заняття, } \\
\text { самостійна } \\
\text { робота }\end{array}$ & $\begin{array}{l}\text { Письмове завдання, } \\
\text { індивідуальний } \\
\text { проєкт, тест, } \\
\text { підсумкова } \\
\text { контрольна робота }\end{array}$ & $10 \%$ \\
\hline & $\begin{array}{l}2.4 \text { вміти виявляти та } \\
\text { виправляти основні } \\
\text { граматичні помилки } \\
\text { (помилки в узгодженні } \\
\text { підмета та присудка, } \\
\text { використанні часів дієслова, } \\
\text { прийменників й артиклів); }\end{array}$ & $\begin{array}{l}\text { Практичне } \\
\text { заняття, } \\
\text { самостійна } \\
\text { робота }\end{array}$ & $\begin{array}{l}\text { Письмове завдання, } \\
\text { індивідуальний } \\
\text { проєкт, тест, } \\
\text { підсумкова } \\
\text { контрольна робота }\end{array}$ & $10 \%$ \\
\hline
\end{tabular}


Продовження

\begin{tabular}{|c|c|c|c|c|}
\hline \multicolumn{2}{|c|}{\begin{tabular}{|c|} 
Результат навчання \\
(1. знання; 2. вміння; \\
3. комунікація; 4. автономія \\
та відповідальність)
\end{tabular}} & \multirow{2}{*}{$\begin{array}{c}\text { Форми } \\
\text { (та/або методи } \\
\text { і технології) } \\
\text { викладання } \\
\text { і навчання }\end{array}$} & \multirow[t]{2}{*}{$\begin{array}{c}\text { Методи } \\
\text { оцінювання }\end{array}$} & \multirow[t]{2}{*}{$\mid \begin{array}{c}\text { Відсоток } \\
\text { у підсумковій } \\
\text { оцінці } \\
3 \text { дисципліни }\end{array}$} \\
\hline Код & Результат навчання & & & \\
\hline & $\begin{array}{l}2.5 \text { вміти написати вдало } \\
\text { структуровану анотацію, яка } \\
\text { здатна привернути увагу до } \\
\text { наукової статті; }\end{array}$ & $\begin{array}{l}\text { Практичне } \\
\text { заняття, } \\
\text { самостійна } \\
\text { робота }\end{array}$ & $\begin{array}{l}\text { Письмове завдання, } \\
\text { тест, підсумкова } \\
\text { контрольна робота }\end{array}$ & $12 \%$ \\
\hline & $\begin{array}{l}2.6 \text { вміти написати наукову } \\
\text { статтю відповідно до вимог } \\
\text { академічного стилю }\end{array}$ & $\begin{array}{l}\text { Практичне } \\
\text { заняття, } \\
\text { самостійна } \\
\text { робота }\end{array}$ & $\begin{array}{l}\text { Письмове завдання, } \\
\text { індивідуальний } \\
\text { проєкт, тест, } \\
\text { підсумкова } \\
\text { контрольна робота }\end{array}$ & $12 \%$ \\
\hline 3 & $\begin{array}{l}\text { Комунікаиія } \\
3.1 \text { грамотно, логічно й } \\
\text { аргументовано формулювати } \\
\text { та висловлювати свою } \\
\text { наукову позицію } \\
\text { англійською мовою; }\end{array}$ & $\begin{array}{l}\text { Практичне } \\
\text { заняття, } \\
\text { самостійна } \\
\text { робота }\end{array}$ & $\begin{array}{l}\text { Фронтальне } \\
\text { опитування, } \\
\text { письмове завдання, } \\
\text { індивідуальний } \\
\text { проєкт, тест, } \\
\text { підсумкова } \\
\text { контрольна робота }\end{array}$ & $5 \%$ \\
\hline & $\begin{array}{l}3.2 \text { ефективно доносити } \\
\text { власну точку зору з метою } \\
\text { привернути увагу до } \\
\text { наукової статті. }\end{array}$ & $\begin{array}{l}\text { Практичне } \\
\text { заняття, } \\
\text { самостійна } \\
\text { робота }\end{array}$ & $\begin{array}{l}\text { Фронтальне } \\
\text { опитування, } \\
\text { письмове завдання, } \\
\text { індивідуальний } \\
\text { проєкт, тест, } \\
\text { підсумкова } \\
\text { контрольна робота }\end{array}$ & $5 \%$ \\
\hline 4 & $\begin{array}{l}\text { Автономність } i \\
\text { відповідальність } \\
\text { критично ставитись до } \\
\text { підбору й аналізу наукових } \\
\text { джерел для написання } \\
\text { власних наукових текстів }\end{array}$ & $\begin{array}{l}\text { Практичне } \\
\text { заняття, } \\
\text { самостійна } \\
\text { робота }\end{array}$ & $\begin{array}{l}\text { Фронтальне } \\
\text { опитування, } \\
\text { письмове завдання, } \\
\text { індивідуальний } \\
\text { проєкт, тест, } \\
\text { підсумкова } \\
\text { контрольна робота }\end{array}$ & $5 \%$ \\
\hline
\end{tabular}


Трубчанінова Т. А., Жигадло О. Ю., Заярна I. С., Клавдіч В. О. Програма навчальної дисципліни “Академічне

6. Співвідношення результатів навчання дисципліни із програмними результатами навчання

\begin{tabular}{|c|c|c|c|c|c|c|c|c|c|c|c|c|}
\hline $\begin{array}{c}\text { Результати навчання } \\
\text { дисципліни (код) } \\
\text { Програмні результати навчання } \\
\text { (назва) }\end{array}$ & 1.1 & 1.2 & 1.3 & 2.1 & 2.2 & 2.3 & 2.4 & 2.5 & 2.6 & 3.1 & 3.2 & 4 \\
\hline $\begin{array}{l}\text { ПРН } 5 \text { Вміти спілкуватися в } \\
\text { діалоговому режимі з широкою } \\
\text { науковою спільнотою та } \\
\text { громадськістю в галузі наукової та } \\
\text { професійної діяльності, в тому } \\
\text { числі і на міжнародному рівні, } \\
\text { демонструючи системний } \\
\text { науковий і культурний світогляд }\end{array}$ & & & & & & & & + & + & + & + & \\
\hline $\begin{array}{l}\text { ПРН } 9 \text { Здійснювати професійну } \\
\text { презентацію результатів своїх } \\
\text { досліджень на міжнародних } \\
\text { наукових конференціях, семінарах, } \\
\text { практично використовувати } \\
\text { іноземну мову (передусім - } \\
\text { англійську) у науковій, інноваційній } \\
\text { та педагогічній діяльності }\end{array}$ & & & + & & & & & + & + & + & + & \\
\hline $\begin{array}{l}\text { ПРН } 13 \text { Вміти кваліфіковано } \\
\text { відображати результати наукових } \\
\text { досліджень у наукових статтях, } \\
\text { опублікованих як у фахових } \\
\text { вітчизняних виданнях, так і у } \\
\text { виданнях, які входять до } \\
\text { міжнародних наукометричних баз }\end{array}$ & + & + & + & & & & & + & + & & & + \\
\hline $\begin{array}{l}\text { ПРН } 14 \text { Вміти використовувати } \\
\text { сучасні інформаційно-комунікаційні } \\
\text { технології при спілкуванні, обміні } \\
\text { інформацією, зборі, аналізі, обробці, } \\
\text { інтерпретації джерел; здійснювати } \\
\text { публікацію джерел з дотриманням } \\
\text { основних археографічних правил }\end{array}$ & & & & + & & + & & + & + & + & & \\
\hline
\end{tabular}

7. Схема формування оцінки.

7.1 Форми оцінювання студентів

- семестрові форми оцінювання:

1. фронтальне опитування - від 3 до 5 балів;

2. письмове завдання - від 3 до 5 балів;

3. тест - від 6 до 10 балів;

4. підсумкова контрольна робота - від 12 до 20 балів. 
Мінімальний бал, який має бути отриманий аспірантом за вищезазначеними формами оцінювання, складає 24 бали. Максимальний бал, який аспірант може отримати за семестр, складає 40 балів. Передбачені форми семестрового оцінювання сумарно не можуть перевищувати 40 балів. Остаточна сума балів за семестр оголошується аспірантам на підсумковому занятті.

- підсумкове оцінювання: письмовий екзамен й індивідуальний проскт

Екзамен складається із двох частин: письмова частина (40 балів) і захист індивідуального проєкту (20 балів).

Письмова частина складається 3 двох частин: перекладу англійською мовою запропонованої під час екзамену анотації загальним обсягом до 150 слів українською мовою та тесту за матеріалами курсу.

Наприкінці практичних занять кожен аспірант готує індивідуальний проєкт. Викладач не менше як за два тижні до кінця практичних занять узгоджує з аспірантами тип і тему проєкту, термін його виконання та вимоги до оцінювання. Після отримання індивідуального завдання аспірант готує проєктну роботу, електронну версію якої має відправити на електронну скриньку викладача не менш як за день до підсумкового заняття з дисципліни (див. останнє заняття за розкладом цієї дисципліни).

Проєкти аспіранти виконують у два етапи: I етап передбачає виконання й оформлення завдання, II етап - представлення результату виконаного завдання, його обговорення та захист.

За індивідуальний проєкт аспірант може отримати до 20 балів, які додаються до суми балів, отриманих під час екзамену. Захист проєктної роботи проводиться під час екзамену.

\begin{tabular}{|l|c|c|c|c|}
\hline & 3М1/Частина 1 & 3М2/Частина 2 & Екзамен & Підсумкова оцінка \\
\hline Мінімум & 12 & 12 & $24+36$ & 60 \\
\hline Максимум & 20 & 20 & $40+20$ & 100 \\
\hline
\end{tabular}

Максимальна підсумкова оцінка за цю дисципліну може становити 100 балів. Аспірант може отримати на іспиті максимально 60 балів, до яких додаються бали, отримані ним на практичних заняттях.

\section{2 Організація оцінювання:}

Види поточного контролю обираються викладачем, який веде практичні заняття, відповідно до цієї програми. Видами поточного контролю можуть бути фронтальне опитування, письмова робота (написання тексту / фрагмента його наукового характеру), тест, підсумкова контрольна робота. При поточному контролі під час практичних занять оцінці підлягають рівень знань, продемонстрований аспірантом у відповіді, активність при виконанні практичних завдань на занятті, систематичність роботи на заняттях, результати виконання письмових робіт, контрольних робіт і домашніх завдань.

Викладач, який проводить практичні заняття, виставляє у визначений термін кількість набраних з поточного контролю балів і заносить їх у відповідний документ обліку успішності аспірантів. У разі відсутності аспіранта на занятті з поважних причин він може відпрацювати пропущене заняття в позааудиторний час (час консультацій викладача) шляхом письмового виконання всіх домашніх завдань і контрольних робіт за пропущений період.

Організація підсумкового оцінювання аспірантів здійснюється в такий спосіб:

- максимальний бал, який може бути отриманий аспірантом за підсумком навчання протягом семестру, складає 40 балів. Мінімальний бал, який має бути отриманий аспірантом за відповідними формами оцінювання, складає 24 бали;

- викладач, який веде практичні заняття, має право звернутись до декана юридичного факультету про недопуск до підсумкового оцінювання аспіранта, якщо під час семестру він 
Трубчанінова Т. А., Жигадло О. Ю., Заярна I. С., Клавдіч В. О. Програма навчальної дисципліни “Академічне письмо англійською мовою” для підготовки здобувачів наукового ступеня доктора філософії в галузі права

не досяг мінімального порогового рівня оцінки (24 бали) тих результатів навчання, які не можуть бути оцінені під час підсумкового контролю. Про недопущення аспіранта до підсумкового оцінювання викладач має подати в деканат юридичного факультету подання з графіком можливих відпрацювань не пізніше, ніж за 10 робочих днів до початку періоду складання заліків. Для аспірантів, які упродовж навчання протягом семестру не досягли мінімального порогового рівня оцінки (24 бали) і внаслідок не допущені до складання підсумкової форми контролю (іспит), проводяться відпрацювання у формі, яка передбачена робочою програмою, максимальна оцінка за яке не може перевищувати кількості балів, що дорівнює різниці між мінімальним пороговим рівнем оцінки (24 бали) та фактичною кількістю балів, отриманих аспірантом за всіма формами поточного контролю;

- якщо аспірант за підсумком відпрацювань не досяг мінімального порогового рівня оцінки (24 бали), викладач, який веде практичні заняття і приймав відпрацювання, звертається до декана юридичного факультету з поданням, в якому фіксує невиконання студентом індивідуального навчального плану;

- за результатами складання підсумкової форми контролю (іспит) аспірант може отримати максимально 60 балів. У разі, коли аспірант під час підсумкової форми контролю, якою є іспит, набрав менше 36 балів, останні не додаються до семестрової оцінки (незалежно від кількості балів, отриманих під час семестру), у відомості в колонці “бали за підсумкову форму оцінювання” ставиться “0”, а в колонку “результативна оцінка” переноситься лише кількість балів, отриманих під час семестру;

- підсумкова оцінка за навчальну дисципліну формується шляхом додавання кількості балів, отриманих протягом семестру, та кількості балів, отриманих за підсумковою формою контролю (іспит), і така сума балів не може бути меншою за 60 балів.

7.3 Шкала відповідності оцінок

\begin{tabular}{|l|c|}
\hline Відмінно / Excellent & $90-100$ \\
\hline Добре / Good & $75-89$ \\
\hline Задовільно / Satisfactory & $60-74$ \\
\hline Незадовільно / Fail & $0-59$ \\
\hline Зараховано / Passed & $60-100$ \\
\hline Не зараховано / Fail & $0-59$ \\
\hline
\end{tabular}

8. Структура навчальної дисципліни. Тематичний план практичних занять

\begin{tabular}{|c|c|c|c|}
\hline \multirow[b]{2}{*}{ № } & \multirow[b]{2}{*}{ НАЗВА ТЕМИ } & \multicolumn{2}{|c|}{ Кількість годин } \\
\hline & & $\begin{array}{c}\text { Практичні } \\
\text { заняття } \\
\end{array}$ & $\begin{array}{c}\text { Самостійна } \\
\text { робота }\end{array}$ \\
\hline \multicolumn{4}{|c|}{ Частина I. Introduction to Academic Writing } \\
\hline 1 & $\begin{array}{l}\text { Topic 1: Academic style: an overview } \\
\text { Study skills for Academic Writing: developing critical } \\
\text { thinking. } \\
\text { Vocabulary for Academic Writing: key nouns/ verbs/ } \\
\text { adjectives /adverbs. } \\
\text { Grammar for Academic Writing: Passive vs. Active. }\end{array}$ & 2 & 9 \\
\hline 2 & $\begin{array}{l}\text { Topic 2: Scholar community and academic etiquette. } \\
\text { Study skills for Academic Writing: avoiding plagiarism. } \\
\text { Vocabulary for Academic Writing: phrasal verbs in } \\
\text { Academic English; key quantifying expressions. } \\
\text { Grammar for Academic Writing: modals and semi-modals. }\end{array}$ & 2 & 9 \\
\hline
\end{tabular}




\begin{tabular}{|c|c|c|c|}
\hline \multirow[b]{3}{*}{ № } & \multirow[b]{3}{*}{ НАЗВА ТЕМИ } & \multicolumn{2}{|r|}{ Продовження } \\
\hline & & \multicolumn{2}{|c|}{ Кількість годин } \\
\hline & & $\begin{array}{c}\text { Практичні } \\
\text { заняття }\end{array}$ & $\begin{array}{c}\text { Самостійна } \\
\text { робота }\end{array}$ \\
\hline \multicolumn{4}{|c|}{ Частина II. Academic Writing in Progress } \\
\hline 3 & $\begin{array}{l}\text { Topic 3: Abstract writing: purpose, types and } \\
\text { content of abstracts. } \\
\text { Study skills for Academic Writing: paraphrasing and } \\
\text { summarizing. } \\
\text { Vocabulary for Academic Writing: words with several } \\
\text { meaning; metaphors and idioms. } \\
\text { Grammar for Academic Writing: relative clauses. }\end{array}$ & 2 & 8 \\
\hline 4 & $\begin{array}{l}\text { Topic 4: Abstract writing: style and layout. } \\
\text { Study skills for Academic Writing: avoiding repetition } \\
\text { and redundancy. } \\
\text { Vocabulary for Academic Writing: word combinations. } \\
\text { Grammar for Academic Writing: conditionals. }\end{array}$ & 2 & 8 \\
\hline 5 & $\begin{array}{l}\text { Topic 5: Paper Writing: title, introduction and } \\
\text { subject matter. } \\
\text { Study skills for Academic Writing: references and } \\
\text { quotations. } \\
\text { Vocabulary for Academic Writing: talking about ideas } \\
\text { and points of view; reporting what others say. } \\
\text { Grammar for Academic Writing: complex subject. }\end{array}$ & 2 & 9 \\
\hline 6 & $\begin{array}{l}\text { Topic 6: Paper Writing : main body, research } \\
\text { techniques, results and conclusions. } \\
\text { Study skills for Academic Writing: organizing } \\
\text { paragraphs, proofreading; bibliography styles. } \\
\text { Vocabulary for Academic Writing: making connections; } \\
\text { comparison and contrasting; presenting an argument, } \\
\text { summary and conclusion. } \\
\text { Grammar for Academic Writing: punctuation. }\end{array}$ & 2 & 15 \\
\hline 7 & Підсумкова контрольна робота & 2 & 12 \\
\hline 8 & Підсумкове заняття & 2 & 2 \\
\hline 9 & Консультація & 2 & \\
\hline
\end{tabular}

Загальний обсяг - 90 год., в тому числі практичні заняття - 16 год., самостійна робота 72 год., консультація - 2 год.

\section{9. Рекомендовані джерела:}

\section{Основні джерела}

Introduction to Academic Writing: Reference and Practice for PhD Students in Law. Вступ до академічного письма: навчальний посібник для здобувачів наукового ступеня доктора філософії в галузі права / О. Жигадло, І. Заярна, Т. Трубчанінова. Херсон : Видавничий дім "Гельветика", 2020. 88 с. Режим доступу: https://drive.google.com/file/d/ 1V2RAbehwFCotdHYTs5MqC_QGjGTJYsCD/view

Guidelines for Abstracts: An American national standard developed by the National Information Standards. - National Information Standards Organization, 1997. Retrieved from http://www.mariapinto.es/ ciberabstracts/Articulos/Z39-14.pdf 
Koopman, Ph. (1997). How to Write an Abstract. - Carnegie Mellon University. Retrieved from https://users.ece.cmu.edu/ koopman/essays/abstract.html

McCarthy, M., \& O’Dell F. (2008). Academic Vocabulary in Use. Cambridge University Press. Retrieved from www.cambridge.org/download file/586108/0/

Jordan, R. R. (1999). Academic Writing Course. Pearson Education Ltd. Retrieved from https://eclass.uoa.gr/modules/.../file.../Jordan,\%20R._Academic_writing_course.pdf

Lynch, T., \& Anderson, K. (2013). Grammar for Academic Writing. Edinburgh, UK: University of Edinburgh. Retrieved from http://www.ed.ac.uk/files/atoms/files/grammar_for_academic_writing ism.pdf

\section{Додаткові джерела:}

Bailey, S. (2011). Academic Writing: A Handbook for International Students (3rd ed.). New York, NY: Routledge. Retrieved from http://cw.routledge.com/textbooks/bailey/

Butler, L. (2006). Fundamentals of Academic Writing. Longman Academic Writing Series, Level 1. Retrieved from https://drive.google.com/file/d/0B3mP_cjd1JnyeFY1QnhPSmNsQ00/ view? $\mathrm{usp}=\mathrm{drivesdk}$

Dyrud, M. A. (2016). Writing for publication. Proceedings of the 2016 IAJC-ISAM International Conference (pp. 1-11). Retrieved from http://cd16.iajc.org/wp-content/uploads/Camera-ready-papers/ 054-X-16_ Writing\%20for\%20Publication\%20_REVISED--Dyrud_.pdf

Hartley, J. (2008). Academic Writing and Publishing: A Practical Guide. New York, NY: Routledge. Retrieved from http://inf.ucv.ro/ mirel/courses/MIAM114/docs/academicwriting.pdf

Hogue, A. (1996). First Steps in Academic Writing. Vol. 1. Longman. Retrieved from https://drive.google.com/file/d/0B3mP_cjd1JnydElUZnIwcEdqSHc/view?usp=drivesdk

Lillis, T., \& Curry, M. J. (2010). Academic Writing in a Global Context. New York, NY: Routledge. Retrieved from https://www.warner.rochester.edu/files/news/files/curry_book_10.pdf

Norris, C. B. (2016). Academic Writing in English. Helsinki, Finland: University of Helsinki. Retrieved from http://www.helsinki.fi/kksc/language.services/AcadWrit.pdf

Savage, A., \& Shafiei, A. (2007). Effective Academic Writing 1 - The Paragraph. Oxford University Press. Retrieved from https://students.mq.edu.au/public/download.jsp?id=249912

Swales, J. M., \& Feak, C. B. (2012). Academic Writing for Graduate Students: Essential Skills and Tasks (3rd ed.). Ann Arbor, MI: University of Michigan.

Swales, J. M., \& Feak, C. B. (2009). Abstracts and the Writing of Abstracts. Ann Arbor: University of Michigan Press. Retrieved fromhttps://www.press.umich.edu/elt/compsite/ETRW/ 9780472034567-commentary.pdf

Swales, J. M., \& Feak, C. B. (2011). Navigating Academia: Writing supporting Genres. Ann Arbor, MI: University of Michigan Press. Retrieved from https:/www.press.umich.edu/script/press/elt/ compsite/ETRW/ 9780472034536-commentary.pdf

Zemach, D. E., \& Rumisek, L. A. (2006). Academic Writing from paragraph to essay. Macmillan, 2006. Retrieved from https://broadyesl.files.wordpress.com/2016/06/academic-writing-fromparagraph-to-essay.pdf.

\section{Електронні ресурси}

Academic Phrasebank. (n.d.). Retrieved from http://www.phrasebank.manchester.ac.uk/.

Purdue Writing Lab. (n.d.). General Format // Purdue Writing Lab. Retrieved from https://owl.english.purdue.edu/owl/resource/560/01/.

Elsevier. (n.d.). Data: Curated. Connected. Complete. Retrieved from https:/www.elsevier.com/ solutions/scopus.

Journal of English for Academic Purposes. (n.d.). Retrieved from https://www.journals.elsevier.com/ journal-of-english-for-academic-purposes/.

International Journal of Legal Studies and Research. (n.d.). Retrieved from http://www.ijlsr.in/.

Oxford Journal of Legal Studies. (n.d.). Retrieved from https://academic.oup.com/ojls/pages/About. 